\title{
ANALISIS INTENSI BERPRESTASI MAHASISWA BINUS ONLINE LEARNING
}

\author{
Agus Putranto; Wawan Saputra \\ aputra@binus.edu,wawans@binus.edu \\ Information Systems Department, School of Information Systems, Binus University \\ Jl. K.H. Syahdan No. 9, Palmerah, Jakarta Barat 11480
}

\begin{abstract}
The utilization of e-learning can improve learning effectiveness and flexibility. Universitas Bina Nusantara (BINUS) provides an online learning program called BINUS Online learning. It offers the student to do a study through online activities, where the students are couraged to learn individually. This research was conducted to obtain a perspective of student intention from BINUS Online learning to mark good achievement. Non experimental method with quatitative approached is implemented where the respondents are students of Information System department and Marketing Management Department. The sampling techniques used is non probability purposive sampling. All variables are measured using questionnaire based on Fishbein and Ajzen model. The data of the research are analyzed using descriptive statistics and multiple linier regression analysis. The results show that the intention to mark an achievement of students of BINUS Online learning is very high $(\bar{*}=686)$.It means that BINUS Online learning Program students have strong intention to get good marks and study achievements.
\end{abstract}

Keywords: intention, study achievement, theory of planned behavior, e-learning

\begin{abstract}
ABSTRAK
Pemanfaatan e-learning dapat meningkatkan efektivitas dan fleksibilitas pembelajaran. Universitas Bina Nusantara (BINUS) memiliki pembelajaran online yang disebut BINUS Online learning. Ini adalah suatu program yang menawarkan para mahasisawa untuk melakukan kegiatan perkuliahan secara online, di mana para mahasiswanya lebih banyak diajak untuk belajar secara mandiri. Penelitian ini dilakukan untuk mendapatkan gambaran intensi atau niat untuk berprestasi pada mahasiswa BINUS Online learning. Subjek pada penelitian ini terdiri dari mahasiswa Jurusan Sistem Informasi dan mahasiswa dari jurusan Management Marketing. Metode penelitian yang digunakan yaitu metode non eksperimen dengan pendekatan kuantitatif. Teknik sampling yang digunakan dalam penelitian ini adalah Nonprobability Purposive Sampling. Seluruh variabel yang ada dalam penelitian ini diukur menggunakan kuesioner yang disusun berdasarkan kuesioner model Fishbein dan Ajzen (2006). Data dari penelitian dianalisis menggunakan analisis Descriptive Statistic dan analisis regresi linier berganda. Hasilnya menunjukkan bahwa intensi untuk berprestasi pada mahasiswa program Online learning Universitas Bina Nusantara sangat tinggi $(\bar{x}=6.68)$. Artinya, mahasiswa program BINUS Online learning memiliki keinginan atau niat yang kuat untuk berprestasi.
\end{abstract}

Kata kunci: intensi, prestasi belajar, theory of planned behavior, e-learning 


\section{PENDAHULUAN}

Pemanfaatan internet untuk mendukung program belajar mengajar sudah mulai dilaksanakan di lingkungan Universitas Bina Nusantara (BINUS University) sejak tahun 1998. Sejak itu, BINUS University mulai menawarkan program Online learning bagi masyarakat yang memiliki kendala untuk mengikuti perkuliahan secara regular. Fleksibilitas melalui metode belajar yang tidak terikat dengan tempat dan waktu tapi tetap fokus menawarkan jaminan kualitas lulusan program Online learning ini akan sama dengan lulusan yang berkuliah secara regular. Online learning menggunakan learning management system (LMS) yang terintegrasi untuk membangun jaringan interaksi antara mahasiswa dengan mahasiswa, mahasiswa dengan dosen dan mahasiswa dengan pembimbing akademis. Dengan demikian mahasiswa online learning dipastikan mempunyai kualitas yang sama dengan mahasiswa yang melakukan sistem perkuliahan pada umumnya. Melalui pembelajaran melalui media online, pembelajaran dapat dilakukan tanpa ada batasan waktu dan tempat, sehingga mahasiswa online akan berasal dari berbagai daerah dan negara yang akan dipandu oleh dosen-dosen BINUS yang tidak hanya berada di Jakarta tetapi juga yang sedang berada di luar negeri. Forum diskusi sebagai media komunikasi antara para mahasiswa dan dosen juga sudah digunakan pada LMS (learning management system) BINUS Online learning.

Dalam mengevaluasi prestasi belajar, seluruh mahasiswa menginginkan tercapainya prestasi belajar yang tinggi, karena prestasi belajar yang tinggi merupakan salah satu indikator keberhasilan proses belajar (Syah, 2006). Namun kenyataannya tidak semua mahasiswa mendapatkan prestasi belajar yang tinggi bahkan terdapat mahasiswa yang mendapatkan prestasi belajar yang rendah. Tinggi dan rendahnya prestasi belajar yang diperoleh dipengaruhi banyak faktor. Prestasi belajar dipengaruhi oleh setidaknya tiga faktor, yaitu: (1) faktor internal (faktor dari dalam siswa), yaitu keadaan atau kondisi jasmani dan rohani; (2) faktor eksternal (faktor dari luar siswa), yaitu kondisi lingkungan di sekitar siswa; (3) faktor pendekatan belajar, yaitu jenis upaya belajar siswa yang meliputi strategi dan metode yang digunakan siswa untuk melakukan kegiatan pembelajaran materi-materi pelajaran (Syah, 2006).

Penelitian ini akan membahas tentang gambaran intensi untuk berprestasi pada mahasiswa program online learning Universitas Bina Nusantara Jakarta yang akan dikaji menggunakan Theory Of Planned Behavior (Ajzen, 1975). Intensi menurut Fishbein dan Ajzen (1975), merupakan komponen dalam diri individu yang mengacu pada keinginan untuk melakukan tingkah laku tertentu. ntensi didefinisikan sebagai dimensi probabilitas subjektif individu dalam kaitan antara diri dan perilaku. Penelitian ini akan menganalisis penggunaan tablet yang akan digunakan untuk mahasiswa BINUS Online learning. Agar penelitian ini tidak melebar, penulis memberikan tiga batasan. Pertama, penelitian menggunakan studi kasus pada BINUS Online learning. Kedua, ada dua jurusan yang akan dianalisis yaitu Sistem Informasi dan Manajemen Marketing. Ketiga, mahasiswa yang disurvei adalah mahasiswa yang sudah mengikuti satu tahun perkuliahan. Tujuan dari penelitian ini adalah untuk mengetahui gambaran intensi untuk berprestasi pada mahasiswa program obnline learning Universitas Bina Nusantara Jakarta. Manfaat penelitian ini dapat dijadikan masukan untuk pengembangan program perkuliahan atau penerimaan mahasiswa baru.

\section{Tinjauan Pustaka}

\section{E-Learning}

Menurut Ruth (2010), kita dapat mengetahui untung rugi dari penerapan e-learning, di mana penerapan e-learning bukan berarti akan menghemat biaya, tetapi membutuhkan biaya yang besar untuk implementasinya seperti biaya pengadaan jaringan, server, maupun infrastruktur teknologi yang 
lainnya. Selain itu belum tentu semua pihak dalam organisasi mendukung $e$ - learning tersebut karena ada beberapa pihak yang takut pekerjaan dan kekuasaan mereka akan terancam dengan adanya $e$ learning ini.

Berdasarkan Tsai (2010), e-learning digunakan untuk dapat menyampaikan materi pelajaran atau pelatihan tanpa adanya batasan tempat dan waktu, yang pada akhirnya akan meningkatkan kualitas dari proses pelatihan tersebut. Untuk mencapai kualitas dari pelatihan juga dibutuhkan kolaborasi dari berbagai jenis e- learning baik yang bersifat synchronous maupun asynchronous.

E-Learning mengacu pada semua kegiatan pelatihan yang menggunakan media elektronik atau teknologi informasi. (Effendi dan Zhuang, 2005).

\section{METODE}

\section{Theory of Planned Behavior}

Theory Reasoned Action (TRA), disusun menggunakan asumsi dasar bahwa manusia berperilaku dengan cara yang sadar dan mempertimbangkan segala informasi yang tersedia, seseorang dapat melakukan atau tidak melakukan suatu perilaku tergantung dari niat yang dimiliki oleh orang tersebut (Gambar 1, Ajzen, 2005).

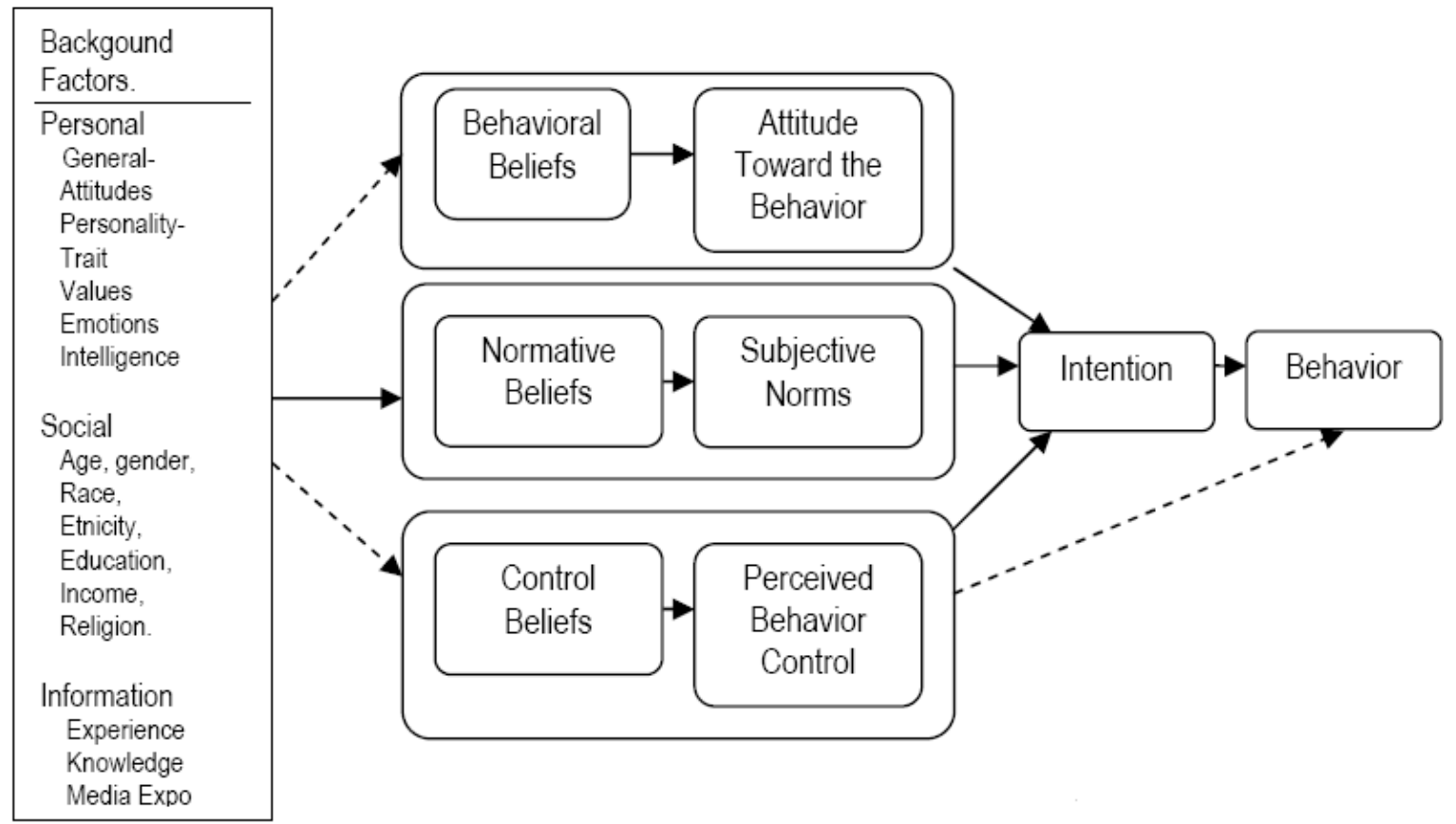

Gambar 1 Teori of Planned Behavior (Ajzen, 2005)

\section{Intensi}

Intensi merupakan suatu kebulatan tekad untuk melakukan aktivitas tertentu atau menghasilkan suatu keadaan tertentu di masa depan. Intensi adalah bagian vital dari Self regulation individu yang dilatarbelakangi oleh motivasi seseorang untuk bertindak. Intensi terbentuk dari Attitude 
Toward Behavior, Subjective Norms, dan perceived behavioral control yang dimiliki individu terhadap suatu perilaku. Berikut ini adalah rumus dari intensi:

$$
B \sim I=\left(A_{B}\right) W_{1}+(S N) W_{2}+(P B C) W_{3}
$$

Keterangan:

$$
\begin{array}{ll}
\mathrm{B} & =\text { behavior } \\
\mathrm{I} & =\text { Intention } \\
\mathrm{AB} & =\text { Sikap (attitude) terhadap perilaku } \\
\mathrm{SN} & =\text { Subjective Norms } \\
\mathrm{PBC} & =\text { Perceived Behavioral Control } \\
\mathrm{W} 1, \mathrm{~W} 2 & \text { \& W3 = weight/bobot }
\end{array}
$$

\section{Variabel Penelitian}

Dalam penelitian ini terdapat dua jenis variabel, yaitu variabel terikat dan variabel bebas. Variabel terikat dalam penelitian ini adalah intensi untuk berprestasi. Definisi operasional dari intensi berprestasi dalam penelitian ini adalah niat individu untuk memiliki prestasi dalam perkuliahannya. Nilai variabel ini diperoleh dari skor skala Likert pada item alat ukur intensi untuk berprestasi. Item yang mengukur intensi ini terdiri dari tujuh alrternatif pilihan jawaban, mulai dari sangat tidak setuju hingga sangat setuju. Semakin besar skor, maka besaran niat mahasiswa untuk berprestasi dalam perkuliahan online learning.

Variabel Bebas terdiri dari: attitude toward behavior, subjective norms, indirect perceived behavioral control, dan direct perceived behavioral control.

Definisi operasional Attitude Toward Behavior dalam penelitian ini adalah sikap yang dimiliki oleh individu mengenai prestasi di dalam perkuliahan. Nilai variabel ini diperoleh dari ratarata penjumlahan skor hasil kali antara skor pada item-item sikap terhadap konsekuensi perlaku dengan skor pada item-item sikap terhadap perlaku yang terlihat dari keyakinan dan evaluasinya terhadap perilaku niat untuk berprestasi.

Definisi operasional dari Subjective Norms dalam penelitian ini adalah ada atau tidaknya dukungan atau hambatan dari orang-orang di sekitar individu yang dapat memengaruhi prestasi dalam perkuliahannya. Nilai variabel ini diperoleh dari skor individu pada skala Subjective Norms yang didapatkan dari penjumlahan hasil kali antara skor pada item-item intensi individu untuk berprestasi.

Dalam penelitian ini, variabel Perceived Behavioral Control dibagi menjadi dua yaitu, Indirect perceived behavioral control dan Direct perceived behavioral control. Definisi operasional dari Indirect perceived behavioral control dalam penelitian ini adalah penilaian individu mengenai kemampuannya mengontrol perilakunya untuk berprestasi ketika dihadapkan dengan faktor luar yang dianggapnya dapat menghambat maupun mendukungnya untuk berprestasi. Nilai variabel ini didapatkan dari rata-rata skor item Indirect perceived behavioral control. Definisi operasional dari Direct perceived behavioral control dalam penelitian ini adalah penilaian individu mengenai kemampuannya mengontrol perilakunya untuk berprestasi ketika dihadapkan dengan faktor dari dalam dirinya yang dianggapnya dapat menghambat maupun mendukungnya untuk berprestasi. Nilai variabel ini didapatkan dari hasil rata-rata skor item Direct perceived behavioral control.

\section{Responden}

Pengambilan data penelitian dilakukan pada tanggal 27 Juni 2012 hingga 13 Juli 2012 menggunakan keusioner secara online. Dari hasil penelitian tersebut diperoleh sebanyak 101 
responden yang berpartisipasi untuk mengikuti penelitian. Mayoritas usia subjek yang berpartisipasi dalam penelitian ini adalah 27 tahun yaitu sebanyak 14 subjek. Usia subjek paling muda yang berpartisipasi dalam penelitian ini adalah 19 tahun yaitu sebanyak 1 subjek. Dan usia subjek yang paling tua yang berpartisipasi dalam penelitian ini adalah 42 tahun yaitu sebanyak 1 subjek.

Subjek berjenis kelamin perempuan dari jurusan Sistem Informasi sebanyak 30 subjek dan subjek berjenis kelamin laki-laki ada sebanyak 15 subjek. Sedangkan mahasiswa dari Jurusan Management Marketing berjenis kelamin perempuan ada sebanyak 20 subjek dan subjek berjenis kelamin laki-laki ada sebanyak 31 subjek.

50 subjek penelitian bertempat tinggal di DKI Jakarta, 30 subjek bertempat tinggal di Jawa Barat, 5 subjek bertempat tinggal di Jawa Tengah, 1 subjek bertempat tinggal di Jawa Timur, 1 responden bertempat tinggal di Kepulauan Riau, 6 responden bertempat tinggal di Banten, dan terdapat 6 responden yang tidak menyebutkan daerah tempat tinggalnya.

\section{Hipotesis Penelitian}

Dari permasalahan yang diangkat dalam penelitian ini, berikut ini adalah hipotesis yang diajukan untuk menjawab permasalahan penelitian ini.

\section{Hipotesis Null (H0)}

H0 1 : Tidak ada pengaruh yang signifikan dari gabungan antara Attitude Toward Behavior, Subjective Norms, dan Indirect perceived behavioral control terhadap intensi untuk berprestasi pada mahasiswa program Online learning Universitas Bina Nusantara Jakarta.

HO 2 : Tidak ada pengaruh yang signifikan dari gabungan antara Attitude Toward Behavior, Subjective Norms, dan Direct perceived behavioral control terhadap intensi untuk berprestasi pada mahasiswa program Online learning Universitas Bina Nusantara Jakarta.

H0 3 : Tidak ada pengaruh yang signifikan dari Attitude Toward Behavior terhadap intensi untuk berprestasi pada mahasiswa program Online learning Unversitas Bina Nusantara Jakarta.

H0 4 : Tidak ada pengaruh yang signifikan dari Subjective Norms terhadap intensi untuk berprestasi pada mahasiswa program Online learning Unversitas Bina Nusantara Jakarta.

H0 5 : Tidak ada pengaruh yang signifikan dari Indirect perceived behavioral control terhadap intensi untuk berprestasi pada mahasiswa program Online learning Unversitas Bina Nusantara Jakarta. H0 6 : Tidak ada pengaruh yang signifikan dari Direct perceived behavioral control terhadap intensi untuk berprestasi pada mahasiswa program Online learning Unversitas Bina Nusantara Jakarta.

\section{Hipotesis Alternatif (Ha)}

Ha 1 : Ada pengaruh yang signifikan dari gabungan antara Attitude Toward Behavior, Subjective Norms, dan Indirect perceived behavioral control terhadap intensi untuk berprestasi pada mahasiswa program Online learning Universitas Bina Nusantara Jakarta.

Ha 2 : Ada pengaruh yang signifikan dari gabungan antara Attitude Toward Behavior, Subjective Norms, dan Direct perceived behavioral control terhadap intensi untuk berprestasi pada mahasiswa program Online learning Universitas Bina Nusantara Jakarta.

Ha 3 : Ada pengaruh yang signifikan dari Attitude Toward Behavior terhadap intensi untuk berprestasi pada mahasiswa program Online learning Unversitas Bina Nusantara Jakarta.

Ha 4 : Ada pengaruh yang signifikan dari Subjective Norms terhadap intensi untuk berprestasi pada mahasiswa program Online learning Unversitas Bina Nusantara Jakarta.

Ha 5 : Ada pengaruh yang signifikan dari Indirect perceived behavioral control terhadap intensi untuk berprestasi pada mahasiswa program Online learning Unversitas Bina Nusantara Jakarta. 
Ha 6 : Ada pengaruh yang signifikan dari Direct perceived behavioral control terhadap intensi untuk berprestasi pada mahasiswa program Online learning Unversitas Bina Nusantara Jakarta.

\section{Alat Ukur Penelitian}

Untuk membuat alat ukur penelitian, dibuat pertanyaan sebagai berikut:

1. Untuk munculkan Attitude Toward Behavior :

a. Menurut Anda, keuntungan apa saja yang Anda dapatkan selama Anda mengikuti program perkuliahan BINUS Online learning di semester ini?

b. Menurut Anda, kerugian apa saja yang Anda dapatkan selama Anda mengikuti program perkuliahan BINUS online learning di semester ini?

c. Menurut Anda, hal-hal apa saja dari program perkuliahan BINUS online learning yang dapat membantu Anda untuk berprestasi dalam perkuliahan di semester ini?

d. Menurut Anda, hal-hal apa saja dari program perkuliahan BINUS online learning yang dapat menghalangi Anda untuk berprestasi dalam perkuliahan di semester ini?

2. Pertanyaan untuk memunculkan Subjective Norms

a. Selama mengikuti program perkuliahan BINUS online learning siapa sajakah yang mempengaruhi dan menginspirasi Anda untuk berprestasi dalam perkuliahan di semester ini?

b. Selama mengikuti program perkuliahan BINUS online learning siapa sajakah yang menghalangi atau tidak mendukung Anda untuk berprestasi dalam perkuliahan di semester ini?

3. Pertanyaan untuk memunculkan Direct perceived behavioral control

a. Dari dalam diri Anda, hal apa sajakah yang mendukung Anda untuk berprestasi dalam perkuliahan program perkuliahan BINUS online learning di semester ini?

b. Dari dalam diri Anda, hal apa sajakah yang menghalangi atau tidak mendukung Anda untuk berprestasi dalam program perkuliahan BINUS online learning di semester ini?

4. Pertanyaan untuk memunculkan Indirect perceived behavioral control

a. Selama mengikuti program perkuliahan BINUS online learning, hal apa sajakah yang berasal dari lingkungan Anda yang mendukung Anda untuk berprestasi dalam perkuliahan di semester ini?

b. Selama mengikuti program perkuliahan BINUS online learning, hal apa sajakah yang berasal dari lingkungan Anda yang tidak mendukung atau menghalangi Anda untuk berprestasi dalam perkuliahan di semester ini?

Dari penyebaran kuesioner online elisitasi data, didapatkan hasil sebagai berikut:

Tabel 1 Hasil Elisitasi Data Attitude Toward Behavior

\begin{tabular}{lclc}
\hline \multicolumn{1}{c}{$\begin{array}{c}\text { Konsekuensi } \\
\text { Positif }\end{array}$} & Frekuensi & Konsekuensi Negatif & Frekuensi \\
\hline $\begin{array}{l}\text { Perkuliahan dapat } \\
\text { dilakukan kapan } \\
\text { saja. }\end{array}$ & 9 & $\begin{array}{l}\text { Jarang ada pertemuan tatap muka } \\
\text { dengan dosen. }\end{array}$ & 10 \\
\hline $\begin{array}{l}\text { Perkuliahan tidak } \\
\text { selalu dilaksanakan } \\
\text { di kampus. }\end{array}$ & 9 & $\begin{array}{l}\text { Tidak dapat bersosialisasi langsung } \\
\text { dgn teman kelas. }\end{array}$ & 3 \\
\hline
\end{tabular}




\begin{tabular}{lll}
\hline $\begin{array}{l}\text { Mendapatkan } \\
\text { pengetahuan baru. }\end{array}$ & 3 & $\begin{array}{l}\text { Harus berusaha sendiri ketika } \\
\text { belajar. }\end{array}$ \\
& & 1 \\
\hline & Weekend terpakai untuk kuliah & 1 \\
\hline
\end{tabular}

Tabel 2 Hasil Elisitasi Data Subjective Norms

\begin{tabular}{lccc}
\hline Pihak Pendukung & Frekuensi & Pihak Penghambat & Frekuensi \\
\hline Keluarga & 9 & Teman yang menggangu saat belajar & 4 \\
\hline Rekan Kerja & 9 & & \\
\hline Pimpinan Kerja & 6 & \\
\hline Dosen & 1 & \\
\hline
\end{tabular}

Tabel 3 Hasil Elisitasi Data Direct Perceived Behavioral Control

\begin{tabular}{lc}
\multicolumn{1}{c}{ Faktor Pendorong } & Frekuensi \\
\hline Adanya semangat belajar & 5 \\
\hline Adanya keinginan untuk mendapatkan gelar sarjana S1 & 4 \\
\hline Untuk mendapatkan karir yang lebih baik & 4 \\
\hline Adanya dorongan dari keluarga. & 9 \\
\hline Adanya dukungan dari sistem online Binus & 4 \\
\hline Adanya dukungan finansial dari kantor & 2 \\
\hline
\end{tabular}

Tabel 4 Hasil Elisitasi Data Indirect perceived behavioral control

\begin{tabular}{lc}
\multicolumn{1}{c}{ Faktor Penghambat } & Frekuensi \\
\hline Adanya rasa malas belajar & 7 \\
\hline Banyaknya pekerjaan di kantor & 6 \\
\hline Banyaknya kesibukan di rumah & 1 \\
\hline
\end{tabular}

Dari hasil elisitasi data yang didapat kemudian disusun ke dalam sebuah kuesioner yang dijadikan sebagai kuesioner utama dalam penelitian ini. 


\section{HASIL DAN PEMBAHASAN}

\section{Analisis Sistem Berjalan}

\section{Proses Bisnis BINUS Online Learning}

Proses Bisnis (Gambar 2) dimulai dari mahasiswa mendaftar melalui Admisi. Calon Mahasiswa melakukan test potensi akademik. Calon Mahasiswa yang lolos test potensi akademik, memasukkan berkas-berkas persyaratan, dan membayar uang kuliah. Calon mahasiswa akan diikutkan ke dalam proses orientasi.

Mahasiswa diberi pengetahuan mengenai Learning Manajemen System (LMS). Fasilitas yang akan digunakan di perkuliahan BINUS Online learning. Dalam orientasi juga dikenalkan dengan Ketua Program Studi, dan Ketua Program Studi memberikan arahan mengenai program studi.

Pada awal minggu pertama, dosen melakukan pertemuan dengan mahasiswa melalui onsite maupun video Conference. Perkuliahan online akan dilakukan dalam 10 minggu. Perkuliahan dilakukan melalui video conference, maupun forum diskusi. Di akhir periode, mahasiswa akan mengikuti perkuliahan tatap muka untuk mengulas ulang materi, membahas kasus atau mempresentasikan tugas. Setelah itu dilakukan ujian untuk mengukur keberhasilan studi mahasiswa.

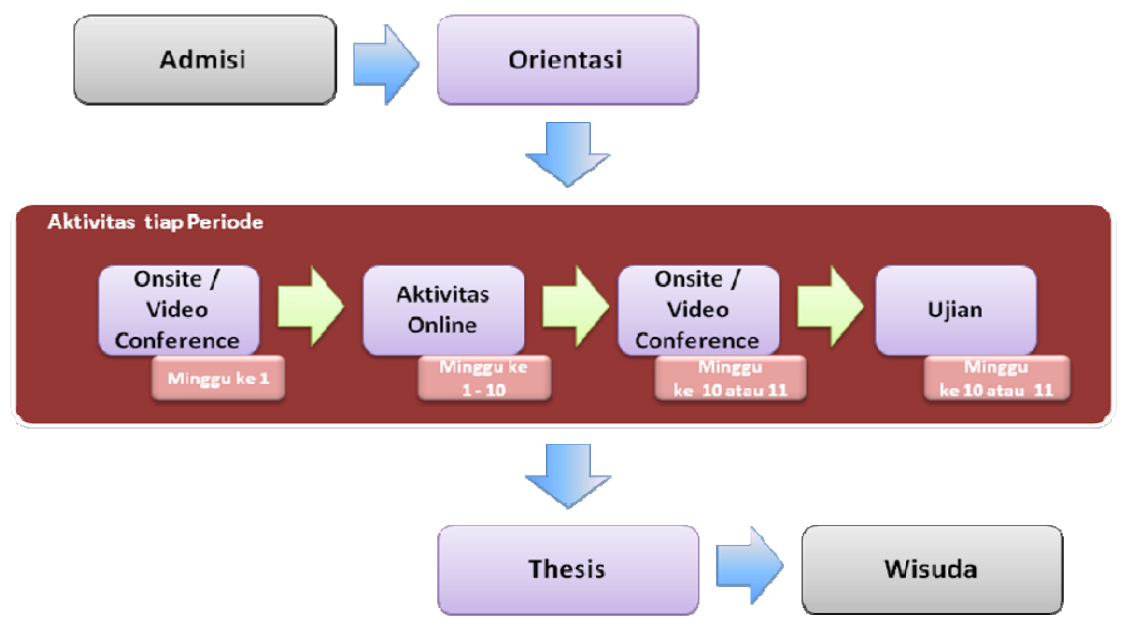

Gambar 2 Bisnis proses BINUS online learning

\section{Sistem Pembelajaran Online}

Pertama, bagian Content Development Staff akan mengunggah konten materi pembelajaran kedalam database LMS Binus Online learning. Setelah itu dosen akan memberikan topik diskusi dan tugas untuk setiap pertemuan, (biasanya batas waktu 1 pertemuan adalah 1 minggu). Kemudian jika ada tugas yang perlu direvisi, maka dosen akan menginformasikan kepada mahasiswa melalui Discussion Forum. Topik diskusi dan tugas tersebut dapat diakses oleh mahasiswa melalui LMS dan Discussion Forum. Topik diskusi dan tugas tersebut nantinya akan dikerjakan oleh mahasiswa dan mengumpulkannya melalui LMS. Kemudian jika terjadi revisi, mahasiswa wajib untuk memperbaikinya sesuai dengan batas waktu yang diberikan oleh dosen. 
Dalam Discussion Forum, Dosen akan menanggapi jawaban topik diskusi yang diberikan oleh setiap mahasiswa, dan jika ada pertanyaan, dosen juga wajib untuk menanggapinya. Dosen membuat penilaian Untuk tugas yang diberikan. Forum diskusi per mata kuliah di bagi menjadi empat forum, yaitu Class Room, Team Room, Meet The Lecture, dan Personal Room, sehingga mahasiswa bisa berdiskusi dengan cara memasuki salah satu forum. Class room adalah tempat bertemu dan berinteraksi antara dosen dengan mahasiswa dalam satu kelas dan satu matakuliah. Dosen membuat topik pembahasan untuk ditanggapi oleh sesama mahasiswa. Mahasiswa juga dapat membuat topik pembahasan untuk ditanggapi oleh dosen atau oleh sesama mahasiswa. Sesama Mahasiswa memberikan tanggapan dan pembahasan topik yang telah diberikan oleh dosen dan sesama mahasiswa. Dosen juga memberikan tanggapan dari pertanyaan atau topik yang diberikan oleh mahasiswa. Dalam team room, satu mahasiswa memberikan tanggapan dan bahasan untuk anggota tim yang lainnya. Sesama Mahasiswa satu kelompok mengakses bahasan yang diberikan oleh teman sekelompoknya. Anggota tim yang lain memberikan tanggapan dari bahasan yang diberikan oleh teman kelompok sendiri. Meet the lecture, adalah forum yang digunakan untuk bertemu dengan dosen secara personal. Mahasiswa memberikan pertanyaan yang sifatnya pribadi untuk dosen yang mau dihubunginya melalui Meet The Lecturer Forum. Dosen mengakses pertanyaan dari Meet The Lecturer Forum. Dosen memberikan tanggapan dan jawaban ke Mahasiswa dari pertanyaan mahasiswa dari Meet The Lecturer Forum. Sedangkan personal room, dosen tidak bisa ikut terlibat dalam forum ini. Mahasiswa memberikan tanggapan dan pembahasan topik antar mahasiswa dikelas itu sendiri. Mahasiswa mendapatkan tanggapan dan pembahasan topik antar mahasiswa dikelas itu sendiri.

Bagian Lecturer Services \& Class Monitoring Staff bertugas untuk mengecek rasio partisipasi mahasiswa ataupun dosen sendiri, untuk mengetahui bahwa keaktifan kelas berjalan dengan baik. Bagian ini pula yang akan membuat sebuah laporan yang berisikan rasio keaktifan dosen yang mengajar di setiap kelasnya, dan laporan tersebut akan dibuat setiap bulannya, memberikan laporan keaktifan dosen dan mahasiswa tersebut kepada Deputy Director yang bertugas untuk memastikan bahwa kelas sudah berjalan dengan baik. Deputy Director akan memberikan peringatan atau teguran bagi dosen yang tidak aktif dalam kegiatan pembelajaran di kelas.

Dosen akan memberikan soal ujian kepada Bagian Thesis \& Graduation Staff. Kemudian bagian Thesis \& Graduation Staff akan melakukan penjadwalan ujian yang akan dilakukan oleh mahasiswa dan melakukan ujian berdasarkan soal ujian yang diberikan oleh dosen mata kuliah. Mahasiswa akan datang ke Binus untuk mengikuti ujian, baik itu UTS maupun UAS dan mengerjakan soal ujian. Bagian Thesis \& Graduation Staff akan memberikan jawaban ujian yang dikerjakan oleh mahasiswa kepada desen yang mengajarnya. Setelah Dosen selesai melakukan penilaian terhadap hasil ujian mahasiswanya, maka Dosen akan mengupload nilai mahasiswa kedalam database melalui LMS.

Mahasiswa dapat mengadukan keluahan-keluhan yang didapatnya di kelas maupun dengan dosen dengan menuliskannya melalui Public Forum, yang di mana forum ini berfungsi sebagai wadah untuk melakukan pertanyaan ataupun keluhan mengenai dunia pembelajaran diluar matakuliah. Keluhan ataupun pertanyaan ini akan dapat diakses oleh Bagian Student Services \& Helpdesk Staff. Bagian Student Services \& Helpdesk Staff akan memberikan tanggapan terhadap keluhan dan pertanyaan yang diajukan oleh mahasiswa.

Sistem pembelajaran online secara ringkas dapat dilihat pada Gambar 3. 


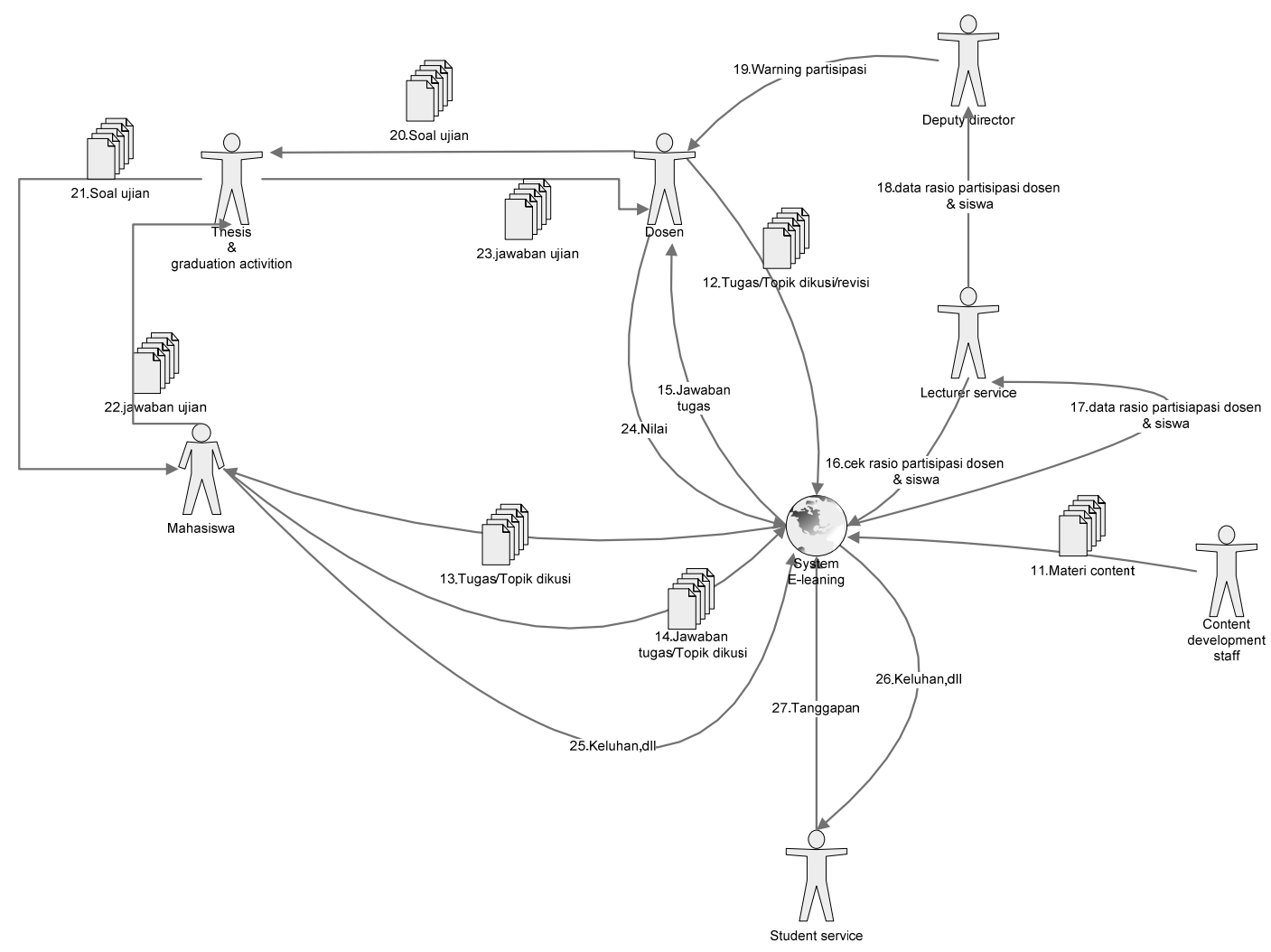

Gambar 3 Rich picture sistem pembelajaran online

\section{Hasil Analisis}

\section{Norma}

Norma (Tabel 5) digunakan sebagai acuan untuk mengetahui gambaran intensi untuk berprestasi pada mahasiswa program BINUS Online learning.

Tabel 5 Norma Intensi untuk Beprestasi

\begin{tabular}{lcc}
\hline \multicolumn{1}{c}{ Variabel } & Rentang Nilai & Kategori \\
\hline Intensi untuk Berprestasi & $1-2,9$ & Rendah \\
& $3-4,9$ & Sedang \\
& $5-7$ & Tinggi \\
\hline Attitude Toward Behavior & $-210--126$ & Rendah \\
& $-125-126$ & Sedang \\
& $124-210$ & Tinggi \\
\hline Subjective Norms & $-84--50,4$ & Rendah \\
& $-50,3-50,4$ & Sedang \\
& $50,5-84$ & Tinggi \\
\hline Indirect perceived behavioral control & $1-2,9$ & Rendah \\
& $3-4,9$ & Sedang \\
& $5-7$ & Tinggi \\
\hline Direct perceived behavioral control & $1-2,9$ & Rendah \\
& $3-4,9$ & Sedang \\
& $5-7$ & Tinggi \\
\hline
\end{tabular}




\section{Analisis Intensi untuk Berpretasi}

Hasil analisis intensi untuk berprestasi pada mahasiswa BINUS Online learning dapat dilihat pada Tabel 6 di bawah ini.

Tabel 6 Intensi untuk Berprestasi

\begin{tabular}{lr}
\hline \multicolumn{1}{c}{ Variabel } & Mean \\
\hline Intensi untuk Berprestasi & 6,68 \\
Attitude Toward Behavior & 57,61 \\
Subjective Norms & 43,3663 \\
Indirect perceived behavioral control & 4,20 \\
Direct perceived behavioral control & 5,7748 \\
\hline
\end{tabular}

Dalam menjawab variabel intensi untuk berprestasi, nilai maksimum sebesar 7 dan nilai minimum sebesar 1. Diperoleh nilai rata-rata sebesar 6,68. Hal ini menunjukkan bahwa intensi untuk berprestasi pada mahasiswa program BINUS Online learning tergolong tinggi.

Nilai rata-rata dari Attitude Toward Behavior sebesar 57,61 dengan rentang nilai yang mungkin diperoleh adalah minimal -210 dan maksimal 210. Hal ini menunjukan bahwa sikap dan penilaian mahasiswa terhadap Binus Online learning tergolong sedang.

Nilai rata-rata dari Subjective Norms adalah sebesar 43,3663 dengan rentang nilai yang mungkin diperoleh adalah minimal -84 dan maksimal 84. Hal ini menunjukan bahwa ada atau tidaknya dukungan atau hambatan dari orang-orang di sekitar mahasiswa yang dapat memengaruhi prestasi dalam perkuliahannya tergolong sedang.

Nilai rata-rata dari Indirect perceived behavioral control adalah sebesar 4,20 dengan rentang nilai yang mungkin diperoleh adalah minimal 1 dan maksimal 7 . Hal ini menunjukan bahwa kemampuan mahasiswa untuk mengontrol perilakunya untuk berprestasi ketika dihadapkan dengan faktor luar yang dianggapnya dapat menghambat maupun mendukungnya untuk berprestasi tergolong sedang.

Nilai rata-rata dari Direct perceived behavioral control adalah sebesar 5,7748 dengan rentang nilai yang mungkin diperoleh adalah minimal 1 dan maksimal 7. Hal ini menunjukan bahwa penilaian mahasiswa mengenai kemampuannya mengontrol perilakunya untuk berprestasi ketika dihadapkan dengan faktor dari dalam dirinya yang dianggap dapat menghambat maupun mendukung mahasiswa untuk berprestasi tergolong tinggi.

Analisis Gambaran Intensi untuk Berprestasi dibandingkan terhadap Attitude Toward Behavior (Attitude), Subjective Norms (SN), Indirect perceived behavioral control (PBCi) dan Direct perceived behavioral control ( $P B C d$ ) (Table 7). Ketiga faktor ini digabungkan yang diharapkan dapat memberikan informasi pengaruh yang lebih jelas.

Tabel 7 Uji Analisis Regresi Linier Berganda (1)

\begin{tabular}{lrrc}
\hline & \multicolumn{3}{c}{ Intensi } \\
\cline { 2 - 4 } & \multicolumn{1}{c}{$\boldsymbol{R}^{2}$} & \multicolumn{1}{c}{$\boldsymbol{F}$} & \multicolumn{1}{c}{ Sig } \\
\hline Attitude, Subjective Norms, dan PBCi & 0,195 & 7,843 & 0,000 \\
Attitude, Subjective Norms, dan PBCd & 0,248 & 10,691 & 0,000 \\
\hline
\end{tabular}


Dari Tabel 7 di atas dapat terlihat bahwa gabungan antara terhadap Attitude Toward Behavior, Subjective Norms, dan Indirect perceived behavioral control mampu menjelaskan variabel intensi untuk berprestasi sebesar 32,8\%. Selain itu gabungan ketiganya memiliki pengaruh yang signifikan terhadap intensi untuk berprestasi $(F=3,885 ; p<0,05)$. Dengan demikian, H01 ditolak. Artinya ada pengaruh yang signifikan dari gabungan antara Attitude Toward Behavior, Subjective Norms, dan Indirect perceived behavioral control terhadap intensi untuk berprestasi pada mahasiswa program BINUS Online learning.

Selain itu, dapat dilihat juga bahwa gabungan antara terhadap Attitude Toward Behavior, Subjective Norms, dan Direct perceived behavioral control juga mampu untuk menjelaskan variabel intense untuk berprestasi sebesar 43,2\%. Dan gabungan ketiganya juga memiliki pengaruh yang signifikan terhadap intensi untuk berprestasi $(F=7,400 ; p<0,05)$. Dengan demikian, H02 juga ditolak. Artinya ada pengaruh yang signifikan dari gabungan antara Attitude Toward Behavior, Subjective Norms, dan Direct perceived behavioral control terhadap intensi untuk berprestasi pada mahasiswa program BINUS Online learning (Tabel 8).

Tabel 8 Uji Analisis Regresi Linier Berganda (2)

\begin{tabular}{lccc}
\hline & & Intensi & \\
\cline { 2 - 4 } & $\boldsymbol{\beta}$ & $\boldsymbol{T}$ & Sig \\
\hline Attitude & 0,327 & 3,437 & 0,001 \\
Subjective Norms & 0,147 & 1,483 & 0,141 \\
PBCi & 0,094 & 0,947 & 0,346 \\
PBCd & 0,337 & 3,565 & 0,001 \\
\hline
\end{tabular}

Pada tabel 8 di atas dapat dilihat bahwa Attitude Toward Behavior memiliki pengaruh yang signifikan terhadap variabel intensi untuk berprestasi $(t=3,437 ; p<0,05)$. Dengan demikian H03 ditolak, yang artinya ada pengaruh yang signifikan dari Attitude Toward Behavior terhadap intensi untuk berprestasi pada mahasiswa program Online learning Unversitas Bina Nusantara Jakarta. Nilai $t$ hitung positif yang berarti bahwa semakin tinggi Attitude Toward Behavior maka semakin tinggi intensi untuk berprestasi yang dimiliki oleh mahasiswa. Begitu pula sebaliknya, semakin rendah Attitude Toward Behavior maka semakin rendah intensi untuk berprestasi mahasiswa. Nilai $\beta$ yang diperoleh adalah 0,327, artinya besaran pengaruh dari Attitude Toward Behavior terhadap intensi untuk berprestasi adalah sebesar 0,327.

Subjective Norms tidak memiliki pengaruh yang signifikan terhadap variabel intensi untuk berprestasi $(t=1,483 ; p>0,005)$. Dengan demikian H04 diterima, yang artinya tidak ada pengaruh yang signifikan dari Subjective Norms terhadap intensi untuk berprestasi pada mahasiswa program Online learning Unversitas Bina Nusantara Jakarta. Nilai $t$ hitung positif yang berarti bahwa semakin tinggi Subjective Norms maka semakin tinggi intensi untuk berprestsi yang dimiliki oleh mahasiswa. Begitu pula sebaliknya, semakin tinggi Subjective Norms maka semakin tinggi intensi untuk berprestasi mahasiswa. Nilai $\beta$ yang diperoleh adalah 0,147, artinya besaran pengaruh dari Subjective Norms terhadap intensi untuk berprestasi adalah sebesar 0,147.

Variabel Indirect Percieved Behavioral Control tidak memiliki pengaruh yang signifikan terhadap variabel intensi untuk berprestasi $(t=0,947 ; p>0,05)$. Dengan demikian H05 diterima, yang artinya tidak ada pengaruh yang signifikan dari Indirect Percieved Behavioral Control terhadap intensi untuk berprestasi pada mahasiswa program Online learning Unversitas Bina Nusantara Jakarta. Nilai $t$ hitung positif yang berarti bahwa semakin tinggi Indirect perceived behavioral control maka semakin tinggi intensi untuk berprestasi yang dimiliki oleh mahasiswa. Begitu pula sebaliknya, semakin rendah Indirect perceived behavioral control maka semakin rendah intensi mahasiswa untuk berprestasi. Nilai 
$\beta$ yang diperoleh adalah 0,094, artinya besaran pengaruh dari Indirect perceived behavioral control terhadap intensi untuk berprestasi adalah sebesar 0,094.

Variabel Direct Percieved Behavioral Control memiliki pengaruh yang signifikan terhadap variabel intensi untuk berprestasi $(t=3,565 ; p<0,05)$. Dengan demikian H05 ditolak, yang artinya ada pengaruh yang signifikan dari Direct Percieved Behavioral Control terhadap intensi untuk berprestasi pada mahasiswa program Online learning Unversitas Bina Nusantara Jakarta. Nilai $t$ hitung positif yang berarti bahwa semakin tinggi Direct perceived behavioral control maka semakin tinggi intensi untuk berprestasi yang dimiliki oleh mahasiswa. Begitu pula sebaliknya, semakin rendah Direct perceived behavioral control maka semakin rendah intensi mahasiswa untuk berprestasi. Nilai $\beta$ yang diperoleh adalah 0,337 , artinya besaran pengaruh dari Direct perceived behavioral control terhadap intensi untuk berprestasi adalah sebesar 0,337

\section{PENUTUP}

Dari penelitian yang telah dilakukan, dapat disimpulkan bahwa: (1) Mahasiswa program online learning Universitas Bina Nusantara memiliki intensi atau niat untuk berprestasi yang tinggi. Artinya, mahasiswa program BINUS Online learning memiliki keinginan atau niat yg kuat untuk berprestasi; (2) gabungan antara Attitude Toward Behavior, Subjective Norms, dan Direct perceived behavioral control, ketiganya juga memiliki pengaruh terhadap intensi untuk beprestasi pada mahasiswa program BINUS Online learning; (3) sikap dan penilaian mahasiswa terhadap Binus Online learning dapat memengaruhi intensi atau niat mahasiswa untuk berprestasi; (4) kemampuan mahasiswa untuk mengontrol kekuatan dari dalam diri mereka untuk berprestasi yang juga memiliki pengaruh terhadap intensi atau niat untuk berprestasi pada mahasiswa program BINUS Online learning; (5) dukungan atau hambatan dari lingkungan sosial mahasiswa, seperti keluarga, dosen, pimpinan kerja, dan sebagainya, serta kemampuan mahasiswa untuk mengontrol hambatan-hambatan yang berasal dari luar atau dari lingkungan mahasiswa untuk berprestasi tidak memiliki pengaruh terhadap intensi atau niat untuk berprestasi dari mahasiswa.

\section{DAFTAR PUSTAKA}

Ajzen, I. (2005). Attitudes, Personality, and Behavior (2nd ed.). New York: Open University Press.

Ajzen, I. dan Fishbein, M. (2005). Theory-based behavior change interventions: Comments on Hobbis and Sutton. Journal of Health Psychology, 10 (1), 27 - 31.

Effendi, Empy dan Zhuang, Hartono. (2005) . E-learning: Konsep dan Aplikasi (edisi 1). Yogyakarta: C.V. Andi Offset.

Ruth, Stephen. (2010). Is e-learning really working? the trillion-dollar question. IEEE Internet Computing, 14 (2), 78 - 82. Diakses 27 Juni 2012 dari http://proquest.umi.com/pqdweb?index $=25 \&$ did $=1977595321 \&$ SrchMode $=1 \&$ sid $=1 \&$ Fmt $=2$ $\underline{\text { \&VInst=PROD\&VType=PQD\&RQT=309\&VName=PQD\&TS=1290947966\&clientId=6884 }}$.

Tsai, August. (2010). An integrated e-learning solution in hospitals. Journal of Global Business Issues, 4 (2), 85 - 93. Diakses 27 Juni 2012 dari

http://proquest.umi.com/pqdweb?index $=8 \&$ did $=2198231821 \&$ SrchMode $=1 \&$ sid $=1 \&$ Fmt $=2 \&$ VInst=PROD\&VType=PQD\&RQT=309\&VName=PQD\&TS=1290947651\&clientId=68814. 